\title{
ASSESSING THE 2019 REDESIGN OF BULGARIAN FISCAL EQUALIZATION SYSTEM
}

\author{
Presiana Nenkova ${ }^{1}$ \\ e-mail:pnenkova@unwe.bg
}

\begin{abstract}
In many countries the narrowing of horizontal fiscal imbalance at local government level is an important issue of national fiscal policy. Large fiscal disparities at municipal level could lead either to lower service levels in fiscally poor regions or to higher tax rates for similar service levels in these regions. In turn, this could thwart efforts to reduce inequality in income distribution between individuals or could induce fiscally inefficient migration of business and individuals. Since the launch of fiscal decentralization reforms in Bulgaria in 2003 part of central government grants system for municipalities has been the equalization grant aimed at financing a minimum level of local services delivery. The equalization formula has undergone many changes during the years, and the last one was implemented in 2019. The main focus of the current study is to compare the equalizing effect of the equalization schemes applied in Bulgaria in 2018 and 2019. In order to test whether the 2018 and 2019 distribution formulas carry an equalizing effect with respect to municipal expenditure needs, per capita transfers received is regressed on three variables or indicators reflecting the differences in the municipal expenditure needs. Our results show that the new equalization mechanism as of 2019 is better designed to capture the differences in municipal expenditure needs and to alleviate fiscal disparities at local level when compared to the mechanism applied in 2018.
\end{abstract}

Key words: fiscal decentralization, fiscal equalization, Bulgaria

JEL: H70, H770

\section{Introduction}

Fiscal equalization is one of the most debated topics in the fiscal decentralization literature. The need for fiscal equalization arises from the fact that in the vertical public sector the supply and financing of public services is distributed among many local governments, some of which have more limited capacity to generate financial resources or greater expenditure needs than others, which affects the quantity and quality of the public services provided in different territorial units. Fiscal disparities at local government level make it impossible for local authorities to deliver comparable levels of public services at a comparable price since

1 Assoc. Prof., PhD, Department of Finance, University of National and World Economy, ORCID: 0000-0003-2948-6502 
"the poorest jurisdictions should exert a higher fiscal effort (higher tax rates) in order to reach a level of expenditures comparable to the richest jurisdictions" (Di Liddo et al., 2015). The existence of a horizontal fiscal imbalance is a prerequisite for inefficient resource allocation and horizontal inequity, and may negatively affect the expected benefits of reforms undertaken towards the decentralization of the public sector, which in turn is an argument in favor of the implementation of some form of fiscal equalization (Boadway and Shah, 2009). The Fiscal equalization "objective is to allow sub-central governments to provide their citizens with similar sets of public services at a similar tax burden" (Blöchliger and Charbit, 2008). Many countries apply a separate category of grants, specifically designed to address fiscal disparities among local governments.

In December 2018, the annual State Budget Act introduced a new formula for determining the budget relationships between central government and municipalities, the only level of local government in Bulgaria. One of the changes involved the equalization mechanism and its redesign. The general equalization grant for local activities has been part of the Bulgarian system of government transfers to municipalities ever since the start of the fiscal decentralization process and the subsequent reforms undertaken in 2003. The many attempts to adjust the equalization formula during the years from 2003 to 2019 is an illustration of a missing consensus on the model of fiscal equalization to be applied in Bulgaria.

The information summarized in Figure 1 shows that the central government in Bulgaria has retained control over the most productive taxes and as a result local government expenditure significantly exceeds own revenue. That explains the strong dependency of local authorities on central budget transfers aimed at compensating the massive vertical fiscal imbalance. At the same time, the central government allocates a very small portion of the budget funds to equalizing fiscal disparities at the local level. The equalization subsidy could in fact be defined also as the only general-purpose grant, applied in Bulgaria and the only one that affords discretionary powers to local governments as to the areas to which the funds can be appropriated. Over the years, its total amount reached, on the average, a mere $0.1 \%$ of the total amount of all subsidies provided to municipalities, and did not exceed more than $0.4 \%$ of the GDP. It can be concluded that Bulgaria's post-2003 fiscal policy did not attach any particular importance to reducing fiscal disparities at the local level. Moreover, the results of a previous study show that despite the positive impact of the equalization subsidy on Bulgaria's horizontal imbalance in terms of narrowing the gap during the years 2007, 2011 and 2017, fiscal disparities at the local level remained large (Nenkova, 2019). 


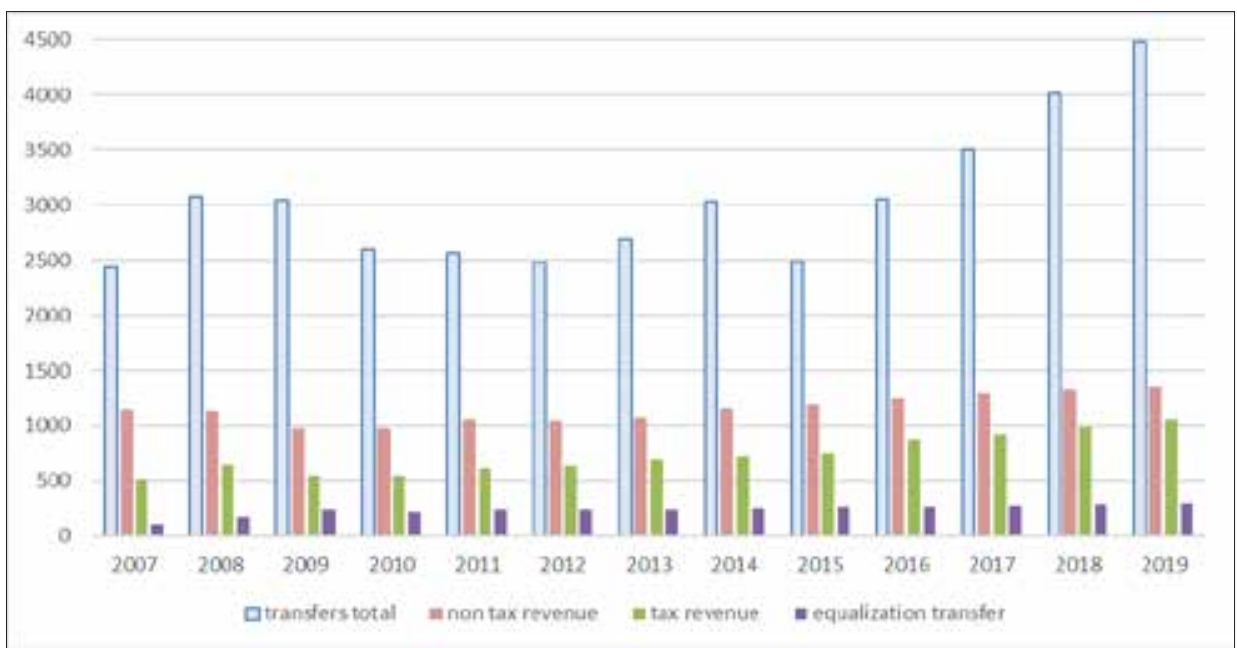

Source: Ministry of finance of the Republic of Bulgaria, author's calculation

Figure 1: Equalization grant importance (2007 - 2019)

This paper aims to achieve two objectives - (1) to provide a comparison between the equalization mechanism applied in 2018 and the new one introduced in 2019 and (2) to explore the effectiveness of the 2019 distributive formula that uses a different approach to reduce the differences in municipal expenditure needs. The paper is structured as follows. The next section discusses the main features of the latest equalization mechanism introduced in Bulgaria since the beginning of 2019. The third section provides an assessment of the equalization formulas, applied in 2018 and 2019 with emphasis on their capability to alleviate the expenditure needs differences and section four draws a conclusion.

\section{The new 2019 formula for allocating general equalization grant among Bulgarian municipalities}

The construction of fiscal equalization scheme requires a decision about: the size of the total pool of funds that will be distributed among local governments and the method of its financing, the design of an allocation formula and the degree of equalization. Transfers designed to equalize, that is to narrow horizontal fiscal imbalance must be lump-sum grants without conditions imposed on local governments. Another rule to follow in constructing an equalization mechanism concerns the distribution formula - it "should be, to the extent possible simple and transparent" which means to "limit its objectives exclusively to the purpose of equalization of fiscal capacity and/or fiscal need "(Martinez-Vazquez and 
Boex, 2000). An issue appearing in the equalization formula design concerns fiscal capacity and expenditure needs measurement. There are different approaches applied in practice "with differences arising from each country's specific budgetary traditions and also from the different degrees of data and information available" (Boex and Martinez-Vazquez, 2007). When constructing the distribution formula, it is also important to measure fiscal capacity and expenditure needs in a way that do not create conditions for local governments strategic behavior, i.e. to unjustifiably increase spending or reduce fiscal effort in order to receive a bigger amount of transfer next year. Another question, arising in fiscal equalization design is the choice between revenue and cost equalization. In general, the unitary countries' practice is to equalize both fiscal capacity and expenditure needs, and federal countries mainly apply a formula aimed at equalizing fiscal capacity only (OECD, 2013).

With the launch of the 2003 Fiscal Decentralization reform, policymakers in Bulgaria introduced a formula-based equalizing mechanism in order to avoid a discretionary grant approach. The lump-sum unconditional fiscal equalization scheme has been organized vertically by the central governments. In 2005 a legally stipulated rule, determining the size of the equalizing pool, was introduced - the total amount of the general equalization grant could not be less than $10 \%$ of the sum of all municipalities' own revenue according to their last annual reports on cash budget execution.

The formula according to which the equalizing fund has been allocated among local governments underwent many changes during the period $2003-2019$. At the beginning the purpose of the equalizing transfer was to allocate additional funds to those municipalities with per capita local tax revenue not exceeding national average or per capita local tax revenue for the country as a whole (Nenkova, 2019). In 2007 a new second component of the equalization formula was introduced in order to compensate local governments with low per capita current expenditure for local activities (excluding salaries, social security contribution and cleaning, garbage collection and disposal). Since then the two main components comprising the distribution formula have been intended to diminish separately the disparities among local governments stemming from the differences between their ability to raise local tax revenue and their ability to cover cost levels necessary to provide local public goods. In fact, all the mechanisms applied after 2007 equalized the differences in tax capacity and expenditure needs separately, which means that the concept behind the general equalization grant was not the 'fiscal gap concept'. The quantification of fiscal capacity and expenditure needs has been based on past values of local tax revenue and current expenditure for local activities. 
In 2018, in terms of tax capacity, the amount of grant received by a particular municipality was linked to its tax revenues, accumulated in 2016 and the distribution of funds was directed to municipalities with per capita tax revenue lower than per capita local tax revenue for the country as a whole. The allocation of funds to equalize the expenditure needs was designed in a way to grant a full access to municipalities with per capita current costs for providing local public services lower than the per capita national average level, and a reduced access to those with higher costs per capita than the per capita national average. Or the equalization through the introduced standards for kindergartens and social home care was not aimed at municipalities with higher spending needs, which objectively had such due to a larger number of children under 5 years or adults over 65, but to municipalities with lower costs for local activities. Thus, the introduced criterion for access to this component took into account the level of own revenues from previous years, rather than the level of the expenditure needs - apparently, the lower levels of spending for local activities was a result of insufficient own revenues. Consequently, municipalities with higher revenue potential due to higher non-tax revenues for example did not have full access to component A1 (see table 1), but were subject to equalization in terms of local tax revenues. Moreover, they were granted an access to component A2, regardless of the fact that in general they may have sufficiently high own revenues, as a result of which their costs per capita for local activities exceeded the per capita national average level (Nenkova, 2021).

Another feature of the fiscal equalization policy during the years was the constant addition of various components, which could hardly be related to the equalization of fiscal disparities among local governments. Funds under one of these components in 2018 were directed to municipalities with a higher collection rate of real estate tax revenues, and the second one had a compensatory nature, such as the provision of funds to ensure the amount of the equalization transfer received by a given local territorial unit during the previous year. In fact, the last component - no municipality receiving an amount less than the amount received in the previous year, worked to some extent against financial equalization (Nenkova, 2021). 
Table 1: A comparison of the 2018 and 2019 equalization mechanisms

\begin{tabular}{|c|c|c|c|}
\hline & & 2018 & 2019 \\
\hline 1 & 2 & 3 & 4 \\
\hline 1. & $\begin{array}{l}\text { Total amount of } \\
\text { funding }\end{array}$ & $\begin{array}{l}\text { Central government decision } \\
\text { Public Finance Law - general } \\
\text { equalization grant amount could } \\
\text { not be less than } 10 \% \text { of the sum } \\
\text { of all municipalities' own revenue } \\
\text { according to their last annual } \\
\text { reports on cash budget execution }\end{array}$ & $\begin{array}{l}\text { Central government decision } \\
\text { Public Finance Law - general } \\
\text { equalization grant amount could } \\
\text { not be less than } 10 \% \text { of the sum } \\
\text { of all municipalities' own revenue } \\
\text { according to their last annual } \\
\text { reports on cash budget execution }\end{array}$ \\
\hline & Access & $\begin{array}{l}\text { No limitations - access granted to } \\
\text { all municipalities }\end{array}$ & $\begin{array}{l}\text { Access denied if per capita local } \\
\text { tax revenue in the prospective } \\
\text { municipality as of December } 31 \text {, } \\
2017 \text { exceeds } 120 \% \text { of per capita } \\
\text { local tax revenue at the national } \\
\text { level, that is the level for the } \\
\text { country as a whole }\end{array}$ \\
\hline 2. & Elements & $\mathrm{A} 1+\mathrm{A} 2+\mathrm{A} 3+\mathrm{A} 4$ & $\mathrm{~A} 1+\mathrm{A} 2+\mathrm{A} 3+\mathrm{A} 4+\mathrm{A} 5$ \\
\hline 3. & $\begin{array}{l}\text { Current } \\
\text { expenditure for } \\
\text { local activities } \\
\text { equalization }\end{array}$ & $\begin{array}{l}\text { Element A1 - aimed to cover } \\
\text { current costs for delivering the } \\
\text { stipulated minimum national } \\
\text { standard of two services - kinder } \\
\text { gardens and home social care for } \\
\text { the elderly. Full access granted if } \\
\text { the municipal per capita current } \\
\text { expenditure for local activities } \\
\text { (excluding salaries, social security } \\
\text { contribution and cleaning, garbage } \\
\text { collection and disposal) as of } \\
\text { December } 31,2016 \text { was lower than } \\
\text { the per capita current expenditure } \\
\text { at the national level while the } \\
\text { other municipalities received only } \\
50 \% \text { coverage of the established } \\
\text { standards for the two types of local } \\
\text { activities }\end{array}$ & $\begin{array}{l}\text { Element A2 - the total sum } \\
\text { of this component is allocated } \\
\text { according to weighted indexes of } \\
\text { expenditure needs } \\
\text { Population - weight } 53.3 \% \\
\text { Municipal roads in km. - weight } \\
10.4 \% \\
\text { Surface area - weight } 23.4 \% \\
\text { Number of people over } 65 \text { years - } \\
\text { weight } 3.8 \% \\
\text { Number of children under } 5 \text { - } \\
\text { weight } 8 \% \\
\text { Number of children between } 6 \\
\text { and } 14 \text { - weight } 1.1 \%\end{array}$ \\
\hline 4. & $\begin{array}{l}\text { Tax revenue } \\
\text { equalization }\end{array}$ & $\begin{array}{l}\text { Element A2 - allocated only to } \\
\text { municipalities with per capita local } \\
\text { tax revenue below the per capita } \\
\text { national level as of December } 31 \text {, } \\
2016 \text {. The equalization applied } \\
\text { was } 85.8 \% \text {. The sum calculated } \\
\text { in this way was corrected with } \\
\text { the level of municipal tax effort } \\
\text { - municipalities that did not exert } \\
\text { the maximum tax effort received } \\
\text { reduced amounts under this } \\
\text { component }\end{array}$ & $\begin{array}{l}\text { Element A } 1 \text { - allocated to cover } \\
\text { the difference between } 120 \% \text { of } \\
\text { per capita local tax revenue at } \\
\text { the country level, that is the level } \\
\text { for the country as a whole and } \\
\text { per capita local tax revenue in } \\
\text { respective municipality }\end{array}$ \\
\hline
\end{tabular}




\section{Continued}

\begin{tabular}{|c|c|c|c|}
\hline 1 & 2 & 3 & 4 \\
\hline 5. & $\begin{array}{l}\text { Additional } \\
\text { element }\end{array}$ & $\begin{array}{l}\text { Element } \mathrm{A} 3 \text { - an additional } \\
\text { component provided to } \\
\text { municipalities with negative } \\
\text { difference between the amount of } \\
\text { components A1 and A2 and the } \\
\text { amount of the equalization transfer } \\
\text { they received according to the State } \\
\text { Budget Law for } 2017\end{array}$ & $\begin{array}{l}\text { Element } \mathrm{A} 3 \text { - an additional } \\
\text { component provided to } \\
\text { municipalities with own revenue } \\
\text { less than } 25 \% \text { of their total } \\
\text { revenue }\end{array}$ \\
\hline 6. & $\begin{array}{l}\text { Additional } \\
\text { element }\end{array}$ & $\begin{array}{l}\text { Element A } 4 \text { - an additional } \\
\text { component, distributed only to } \\
\text { municipalities that have reported } \\
\text { a collection rate of property tax } \\
\text { revenue for } 2016 \text { above the average } \\
\text { collection rate of } 73.43 \%\end{array}$ & $\begin{array}{l}\text { Element A4 - an additional } \\
\text { component provided to } \\
\text { municipalities with negative } \\
\text { difference between the amount } \\
\text { of components A1 and A } 2 \\
\text { and A3 and the amount of } \\
\text { the equalization transfer they } \\
\text { received according to the State } \\
\text { Budget Law for } 2018\end{array}$ \\
\hline 7. & $\begin{array}{l}\text { Additional } \\
\text { element }\end{array}$ & & $\begin{array}{l}\text { Element A5 - an additional } \\
\text { component provided to } \\
\text { municipalities that exerted tax } \\
\text { effort exceeding the average tax } \\
\text { effort for the country as a whole. } \\
\text { The tax effort is calculated as the } \\
\text { sum of ratios between tax rates of } \\
\text { four local taxes set by the local } \\
\text { government in the respective } \\
\text { municipality and the maximum } \\
\text { rates of these taxes as determined } \\
\text { by the law. The sum of four ratios } \\
\text { is then divided by four. }\end{array}$ \\
\hline
\end{tabular}

Source: State Budget Act of the Republic of Bulgaria for 2018 and 2019.

At the end of 2018 the equalizing formula was revised again and as a result of its application in 2019, for the first time after 2008 a few municipalities were not granted an access to the equalizing fund. The reason lies in the newly introduced criterion for access, which does not allow local territorial units to receive funds from the equalization pool if their level of per capita tax revenue as of 31.12.2017 exceeds 120 percent of the per capita local tax revenue for a country as a whole. The distribution formula already includes five elements, the purpose of the first - A1 being to equalize the differences in local tax revenue, so that after equalization each municipality's per capita local tax revenue equals 
120 percent of the national average per capita local tax revenue. A completely different approach is applied in order to equalize the differences in expenditure needs. The distribution formula no longer accounts for the implemented in previous years actual costs of local activities. Expenditure needs for each local government are approximated by applying a weighted index of six variables or needs' factors - population, area, municipal roads length, the number of children under 5, the number of children over 6 and under 14, and the number of adults over 65. It is supposed that the choice of factors is based on an analysis of the main determinants of differences in municipal expenditure needs. According to the State Budget Act of 2019, the weight of each factor is determined depending on the cost structure of local activities across 265 municipalities.

The equalization mechanism that has been introduced in 2019 also included additional components such as the compensatory element A4 and also additional funds were provided to municipalities whose share of own revenue was less than 25 percent of their total revenue. A further policy decision introduced in 2019 was to stimulate tax effort of local governments not to punish them for deciding tax rates lower than the maximum stipulated by the law (see table 1). Funds under component A5 are distributed to municipalities that exerted tax effort exceeding the average tax effort for the country as a whole.

\section{Evaluating 2018 and 2019 equalization mechanisms}

The main expected result from fiscal equalization policy is "to reduce, or even eliminate, fiscal disparities among provincial or local governments" (Dafflon, 2007). There are numerous studies analyzing the effectiveness of fiscal equalization schemes applied in different countries. The empirical literature resorts to two approaches to assess the inequality reducing effect of an equalization mechanism. The first one compares the original or pre-grant per capita inequality and postgrant or final per capita inequality (Hofman et al., 2006). For example, Primorac examined the effectiveness of fiscal equalization policy in Croatia by comparing the degree of a local government unit's fiscal capacity inequality before and after fiscal equalization (Primorac, 2015). The other approach uses regression analysis to reveal the relationship between per capita equalization grant as a dependent variable and some proxies of fiscal capacity and expenditure needs as the independent variables. A study of the World bank (2000) applied regression with per capita grant as the dependent variable and per capita provincial GDP as the independent variable to test the disparity reducing effect of equalization transfers in China. Brodjonegoro and Martinez-Vazquez (2002) also performed a series of regressions to explain the distribution of the equalization grant in Indonesia. For explanatory variables on the expenditure need side they used two variables included in the equalization formula - the construction price index and the 
percent living in poverty, as well as other variables that approximate expenditure need - percent of the population of retirement age, percent of population younger than working age, and population density. Martinez-Vazquez and Boex (2001) regressed per capita equalization transfers by per capita gross regional product (GRP) and several measures of need - cost of living, percentage of the population under and over working age, and percentage living in poverty to find if the FFSR transfers in Russia equalized between 1994 and 1997.

The current study applies both approaches to evaluate the disparity reducing effect of fiscal equalization in Bulgaria. First, it compares pre-grant per capita own revenue inequality and post-grant per capita inequality in 2018 and in 2019 respectively. Second, it uses regression analysis to determine the relationship between per capita equalization grant, received by each municipality in 2018 and 2019 as the dependent variable and three variables included in the 2019 distributive formula as the independent variables.

There are considerable differences among Bulgarian municipalities in terms of own revenue per capita. In 2019, for example, 196 municipalities had own revenue per capita of BGN 300, while in 49 municipalities the own revenue per capita ranged from BGN 301 to BGN 500, and in 20 municipalities, own revenue per capita exceeded BGN 500, reaching maximum values of BGN 4201. Since the general equalization subsidy does not involve any conditions, and it brings up the level of municipal own revenue, the differences in terms of the sum of own revenue and the equalization subsidy per capita practically represent the resulting differences in terms of own revenue after the subsidy has been allocated. The information in Table 3 shows that, after the award of the equalization subsidy in 2019, the inequality as measured by the coefficient of variation goes down significantly in the largest group of municipalities. In 2019 this group A includes 196 municipalities with per capita own revenue not exceeding the per capita own municipal revenue at the country level. On the contrary, the subsidy does not affect the pre-grant own revenue inequality in Group B and Group C. I.e., the equalization subsidy is aimed primarily at increasing per capita own revenue in the poor municipalities. For comparison, in 2018, the equalization subsidy similarly led to a drop in the value of the coefficient of variation in Group A, or that of the poorest municipalities and did not cause any change to the values of the coefficient of variation in Group B before and after the award of the subsidy. The difference is in the equalization effect on the municipalities from Group C, i.e. those 20 municipalities having the highest level of per capita own revenue. The formula applied in 2018 results in a decrease in the values of the coefficient of variation in that group, from 0.84 prior to the subsidy to 0.79 post-subsidy. In 2019 , there was no change to the values of the coefficient of variation after the subsidy given that, out of those 20 municipalities having the highest per capita 
own revenue, 12 were not eligible for any equalization subsidy because their per capita local tax revenue exceeded $120 \%$ of the per capita local tax revenue at the country level. The remaining 8 municipalities were eligible for the equalization subsidy, because their per capita tax revenue did not exceed $120 \%$ of the national average, although their per capita own revenue was among the highest due to the considerable non-tax revenue.

Table 2: Fiscal Revenue (own) per capita before equalization (BGN)

\begin{tabular}{|l|l|l|l|l|l|l|l|}
\hline \multicolumn{1}{|c|}{$\mathbf{2 0 1 8}$} & \multicolumn{1}{c|}{ A } & \multicolumn{1}{c|}{ B } & \multicolumn{1}{c|}{ C } & \multicolumn{1}{|c|}{$\mathbf{2 0 1 9}$} & A & B & C \\
\hline $\begin{array}{l}\text { Number of } \\
\text { municipalities }\end{array}$ & 196 & 49 & 20 & $\begin{array}{l}\text { Number of } \\
\text { municipalities }\end{array}$ & 196 & 49 & 20 \\
\hline Min & 80 & 296 & 476 & Min & 89 & 301 & 505 \\
\hline Max & 290 & 464 & 4480 & Max & 300 & 487 & 4201 \\
\hline Average & 195 & 356 & 1113 & Average & 208 & 379 & 1083 \\
\hline $\mathrm{CoV}$ & 0.27 & 0.14 & 0.84 & $\mathrm{CoV}$ & 0.27 & 0.14 & 0.80 \\
\hline $\mathrm{CoV}_{\text {before }}$ & 1.19 & & $\mathrm{CoV}_{\text {before }}$ & 1.08 & \\
\hline
\end{tabular}

Source: National Association of Municipalities of the Republic of Bulgaria, author's calculations

Table 3: Fiscal Revenue (own + equalization transfer) per capita after equalization (BGN)

\begin{tabular}{|l|c|c|l|l|l|l|l|}
\hline \multicolumn{1}{|c|}{$\mathbf{2 0 1 8}$} & \multicolumn{1}{c|}{ A } & \multicolumn{1}{c|}{ B } & \multicolumn{1}{c|}{ C } & \multicolumn{1}{c|}{$\mathbf{2 0 1 9}$} & A & B & C \\
\hline $\begin{array}{l}\text { Number of } \\
\text { municipalities }\end{array}$ & 196 & 49 & 20 & $\begin{array}{l}\text { Number of } \\
\text { municipalities }\end{array}$ & 196 & 49 & 20 \\
\hline Min & 166 & 332 & 526 & Min & 187 & 348 & 529 \\
\hline Max & 392 & 617 & 4522 & Max & 487 & 638 & 4254 \\
\hline Average & 271 & 412 & 1150 & Average & 300 & 437 & 1110 \\
\hline CoV & 0.17 & 0.14 & 0.79 & CoV & 0.17 & 0.14 & 0.79 \\
\hline CoV $_{\text {after }}$ & 0.95 & & CoV $_{\text {after }}$ & 0.84 & & \\
\hline
\end{tabular}

Source: National Association of Municipalities of the Republic of Bulgaria, author's calculations

In order to test whether the 2018 and 2019 distributive formula carries an equalizing effect with respect to municipal expenditure needs, per capita transfers received are regressed on three variables or indicators reflecting the differences in the municipal expenditure needs. In the presence of an equalizing effect the 
regression coefficients would be statistically significant and positive. To perform the above analysis, the following equation is estimated:

$$
Y_{i}=\alpha+\beta X_{i}+\varepsilon i
$$

The dependent variable $\mathrm{Y}$ represents the per capita equalization transfer received by every single municipality in 2018 and 2019. The matrix $X$ represents a set of control or independent variables - surface area, children under 5 and elderly over 65 . The choice of the three variables is based on the fact that they were included in the 2019 distribution formula. In 2018 each municipality with full access to component A1 received an amount equal to a national lump-sum standard per a child under 5 and per a person over 65 according to the predetermined coverage $-43 \%$ of children under 5 living on the territory of the particular municipality and $3 \%$ of people over 65 living on the territory of the particular municipality. Therefore, one should expect that the number of children and the number of elderlies would have a positive effect on the per capita equalization transfer received in 2018 . The variable population is excluded from the multiple regression model due to the presence of a high intercorrelation between the two independent variables - population and children under 5 and between the two independent variables - population and elderly over 65 .

The influence of the three factors, used as proxies of expenditure needs in the 2019 distributive formula on the allocation of transfers, is analyzed with the data presented in table 4. 2018 and 2019 number of observations differs because 19 municipalities did not have access to equalization grant in 2019. The positive and statistically significant regression coefficients for all the independent variables in 2019 support the notion that the new distribution formula works to equalize expenditure needs, i.e. the per capita equalization transfer tends to increase with population over 65 , children below 5 and surface area. On the contrary, area, children under 5 and elderly over 65 did not affect the allocation of funds aimed at reducing disparities in expenditure needs in 2018. The estimation results show that both the surface area and population over 65 negatively correlate with the amount of received per capita equalization transfer in 2018 and only the population over 65 is statistically significant. Children under 5 have a positive sign, but it is statistically insignificant. However, the value of $\mathrm{R}^{2}$ may be interpreted as a missing correspondence between the distribution of the equalization transfer in 2018 and variables such as children under 5, population over 65 and surface area. 
Table 4: Estimation results

\begin{tabular}{|c|c|c|}
\hline & $\begin{array}{l}\text { Independent variable: } \\
\text { Per capita equalization } \\
\text { transfer }\end{array}$ & $\begin{array}{c}\text { Independent variable: } \\
\text { Per capita equalization } \\
\text { transfer }\end{array}$ \\
\hline & 2018 & 2019 \\
\hline Constant & $\begin{array}{l}80.60215^{*} \\
(0.00)\end{array}$ & $\begin{array}{l}32.10470 * \\
(0.00)\end{array}$ \\
\hline Surface area & $\begin{array}{l}-0.004467 \\
(0.6070)\end{array}$ & $\begin{array}{l}0.045818^{*} \\
(0.02)\end{array}$ \\
\hline Population age over 65 & $\begin{array}{l}-0.003223 * \\
(0.0048)\end{array}$ & $\begin{array}{l}0.008951 * \\
(0.00)\end{array}$ \\
\hline Population age under 5 & $\begin{array}{l}0.00625 \\
(0.1478)\end{array}$ & $\begin{array}{l}0.053279 * \\
(0.00)\end{array}$ \\
\hline $\mathrm{R}^{2}$ & 0.174283 & 0.834166 \\
\hline Adjusted $\mathrm{R}^{2}$ & 0.164492 & 0.832049 \\
\hline F-stat & $\begin{array}{l}17.80 \\
(0.00)\end{array}$ & $\begin{array}{l}394.03 \\
(0.00)\end{array}$ \\
\hline Observations & 265 & 246 \\
\hline
\end{tabular}

Note: standard errors in parentheses ( $\mathrm{p}$-value), ${ }^{*} \mathrm{p}<0,05$

Source: author's calculations

The above stated confirms the effectiveness of the new distributive formula the municipalities with higher expenditure needs, i.e. those with more needy population over 65, a bigger surface area or more children under 5 receive a larger equalization transfer per capita in 2019. The value of $\mathrm{R}^{2}$ is 0.83 , which implies that 83 percent of the variations of per capita equalization transfers can be explained by variations in these three factor variables.

\section{Conclusion}

Through the equalization subsidy in Bulgaria, the funds redistributed among municipalities amount to $0.4 \%$ of the GDP on average during the period 2003 2019. Although the manner in which the 2019 equalization subsidy funds were allocated managed to capture better the differences in the expenditure needs and, unlike the formula applied in 2018, serves better the purpose of distributing the funds according to municipal expenditure needs, it is also not free from certain shortcomings. The separate equalization of expenditure needs and revenue 
capacity as measured in terms of tax revenue has continued, and again there are municipalities which, despite their high revenue potential and their ability to meet their expenditure needs, as determined under the methodology of the Ministry of Finance, continue to receive a subsidy. Access to the subsidy is determined by the tax capacity and, in the way it is defined, the eligibility criterion assumes that municipalities having a high tax capacity can meet their expenditure needs, while failing to take account of the level of non-tax revenue. Consequently, in determining revenue capacity, not all of the local sources of revenue are taken into account; hence, in practice, certain municipalities are qualified as being poorer than they actually are in terms of their total own revenue.

\section{References}

Blöchliger, H., Cahrbit, C. (2008). Fiscal Equalization, OECD Economic Studies 44, 2008/1, available at: https://www.oecd.org/norway/42506135.pdf (accessed 29.04.2021)

Boex, J., Martinez-Vazquez, J. (2007). Designing Intergovernmental Equalization Transfers with Imperfect Data: Concepts, Practices, and Lessons, in Martinez-Vazquez, J. and Searle, B. (eds), Fiscal Equalization, Springer, Boston, MA.

Boadway, R., Shah, A. (2009). Fiscal Federalism: Principles and Practice of Multiorder Governance, Cambridge University Press, New York.

Brodjonegoro, B., Martinez-Vazques, J. (2008). An Analysis of Indonesia's transfer System: Recent Performance and Future Prospects, International Center for Public Policy at Andrew Young School of Policy Studies, GSU, ISPWPS Working Paper 02-13, available at: https://icepp.gsu.edu/ files/2015/03/ispwp0213.pdf (accessed 05.05.2021)

Dafflon, B. (2007). Fiscal Capacity Equalization in Horizontal Fiscal Equalization Program. In Boadway, R. and Shah, A. (eds.), Intergovernmental Fiscal Transfers: Principles and Practice, Washington, D.C.: The World Bank, pp. 361-396.

Di Liddo, G., Longobardi, E., Porcelli, F. (2015). Fiscal Imbalance and Fiscal Performance of Local Governments: Empirical Evidence from Italian Municipalities, Preprint paper, available at: https://www.siecon.org/sites/siecon.org/ files/oldfiles/uploads/2015/10/Porcelli.pdf (accessed 23.04.2021)

Hofman, B., Kadjatmiko, Kaiser, K., Sjahrir, B. S. (2006). Evaluating Fiscal Equalization in Indonesia, Policy Research Working Paper, No 3911, World Bank, Washington, DC.

Martinez-Vazquez, J., Boex, J. (2001). Russia's Transition to a New Federalism, Washington, D.C.: The World Bank, WBI Learning Resource Series 15248, 
available at: https://openknowledge.worldbank.org/handle/10986/15248 (accessed 23.04.2021)

Martinez-Vazques, J., Boex, J. (2000). The Design of Equalization Grants: Theory and Applications, Part one, World Bank Institute/Andrew Young School of Policy Studies, GSU, available at: http://www.decentralization.net/wp-content/uploads/2018/05/ModulePartOne.pdf (accessed 23.04.2021)

Ministry of finance of the Republic of Bulgaria, Annual Reports on State Budget Execution (2007 - 2019).

National Association of Municipalities of the Republic of Bulgaria. Local Finance Internet Platform, available at: http://www.namrb.obuchi-se.org/norway/bg-bg/\%D0\%BD \%D0\%B0\%D1\%87\%D0\%B0\%D0\%BB\%D0\%BE. aspx

Nenkova, P. (2021). Fiskalna detsentralizatsia v Bulgaria - vertikalno neravnovesie i horizontalni razlichia, Izdatelski kompleks - UNSS, Sofia.

Nenkova, P. (2019). An Analysis of Equalizing Capacity of State Transfers for Local Government Activities in Bulgaria, Economic Alternatives, issue 4, pp. 627-640.

OECD. (2013). Fiscal Federalism 2014: Making Decentralization Work, Chapter 5, Fiscal Equalization: A Key to Decentrilized public Finance, OECD Publishing Paris.

Primorac, M. (2015). The Effectiveness of Fiscal Equalization in Croatia, Economic research, vol. 28(1), pp. 299-311, available at: from https://hrcak.srce. $\mathrm{hr} / 171515$ (accessed 23.04.2021)

State Budget Act of the Republic of Bulgaria for 2018 and 2019.

World Bank. (2000). China: Managing Public Expenditures for Better Results - Country Economic Memorandum, Report No 20342-CHA, available at: http://documents1.worldbank.org/curated/en/755191468240587169/pdf/ multi-page.pdf (accessed 02.04.2021) 